\author{
Mona Ekawati ${ }^{1}$ \\ Nevi Yarni ${ }^{2}$
}

\section{TEORI BELAJAR BERDASARKAN ALIRAN PSIKOLOGI HUMANISTIK DAN IMPLIKASI PADA PROSES BELAJAR PEMBELAJARAN}

\begin{abstract}
Abstrak
Pada psikologi humanistik pendidik sebagai fasilitator. Pendidik humanistik diharapkan menjadi pendidik manusiawi sehingga pendidik bisa mengarahkan peserta didik untuk meningkatkan potensi dirinya. pendidik akan melaksanakan pembelajaran dan peserta didik belajar dari pengalaman mereka sendiri. Pendidik membimbing siswa dengan tidak membebani peserta didik dalam pembelajaran tetapi menanamkan nilainilai atau perilaku positif dan perilaku negatif. Teori humanistik bertujuan memanusiakan manusia seutuhnya yang kaffah sebagai makhluk ciptaan Allah SWT. Tujuan penulisan jurnal ini adalah untuk membahas teori belajar berdasarkan aliran psikologi humanistik dan implikasi pada proses belajar pembelajaran. Mengolah informasi dari ransangan fisik seperti cahaya, panas, tekanan udara, serta suara ditangkap dapat diserap secara cepat dalam system indera jangka pendek. informasi akan simpan di short time memory dalam sistem kerja otak manusia. dan menjadi long time memory jika informasi ini terus diberikan secara berulang
\end{abstract}

Kata Kunci: Psikologi, Humanistik

\begin{abstract}
Psychology of humanistic gives full attention for the teachers as a facilitator. The effective teachers can be called human teachers. Humanistic helps students to develop themselves based on the potential that they have. The teachers will have teaching learning process, and the student learn from their experience. The teacher guides the students not by burdening the students on teaching learning process, but implant the moral value or positive and negative attitude. The aim of humanistic theory is humanize the people in order to be able to comprehend their environment and themselves. As well as in educational paradigm, humanistic faces human as human it is a creative created by Allah with certain nature. The aim of this journal is to discuss about learning theory based on humanistic psychology and its implication in teaching learning process. The processing of information from physic stimulus such as lighting, warm, atmosphere, and the caught sound can be kept fastly by short-term sensing system. If the information is watched out for, the information will be translated by short term memory in working memory shelter system, and will be saved in long-term memory if it is repeated and encoded, it will be kept by student long term memory.
\end{abstract}

Keywords: Psychology, Humanistic

\footnotetext{
${ }^{1}$ Mahasiswa Prodi Ilmu Pendidikan, Universitas Negeri Padang Alamat email Mona.ekawati@ypitmutiara.sch.id

${ }^{2}$ Dosen/Staf pengajar Prodi Ilmu Pendidikan, Universitas Negeri Padang
} 


\section{PENDAHULUAN}

Teori humanistik bertujuan menjadikan manusia seutuhnya sehingga dapat paham terhadap perubahan alam semesta dan diri peserta didik sendiri. Pendidikan humanistik menjadikan manusia seutuhnya, sebagai makhluk Allah SWT di karuniai fitrah sebagai manusia. Manusia pada pendidikan humanistik bersifat kemanusiaan yang dilihat secara filosofis, dengan hal ini paradigma pendidikan memilki harapan besar terhadap nilai pragmatis iptek tidak bisa mematikan kepentingan dan kemanusiaan. Sehingga peserta didik terjaga dari dampak negatif teknologi serta keadaan kehidupan manusia menjadi kondusif dan aman.

Psikologi humanistik mengarahkan pendidik sebagai fasilitator. Pendidik humanistik adalah pendidik yang manusiawi. Psikologi humanistik mengarahkan peserta didik untuk meningkatkan potensi intelektual yang peserta didik miliki. Pendidik membimbing siswa dengan tidak membebani peserta didik di proses pembelajaran tetapi menanamkan nilai-nilai atau perilaku positif dan perilaku negatif.

\section{PEMBAHASAN}

Teori humanistik bertujuan menjadikan manusia seutuhnya yang melek terhadap perubahan alam semesta dan diri peserta didik sendiri. Teori humanistik bertujuan menjadikan manusia seutuhnya sehingga dapat paham terhadap perubahan lingkungan dan dirinya sendiri. Pendidikan humanistik menjadikan manusia seutuhnya, sebagai makhluk Allah SWT dikaruniai fitrah sebagai manusia. Manusia pada pendidikan humanistik bersifat kemanusiaan yang dilihat secara filosofis, dengan hal ini paradigma pendidikan memilki harapan besar terhadap nilai pragmatis iptek tidak bisa mematikan kepentingan dan kemanusiaan. Sehingga peserta didik terjaga dari dampak negatif teknologi serta keadaan kehidupan manusia menjadi kondusif dan aman.

Psikologi humanistik menganjurkan pendidik sebagai fasilitator. Pendidik humanistik adalah pendidik yang manusiawi. Psikologi humanistik mengarahkan peserta didik untuk meningkatkan potensi intelektual yang peserta didik miliki. Pendidik membimbing siswa dengan tidak membebani peserta didik di pembelajaran tetapi menanamkan nilai-nilai atau perilaku positif dan perilaku negatif.

Proses pengajaran humanistik, multiple intelegency peserta didik berbeda harus dipahami oleh pendidik yang hebat. pengajaran humanistik, menitik beratkan kepada ide -ide siswa yang dianggap sebagai ide yang unik menurut teori, praktik dan keadaan kehidupan mereka. Contoh model-model pembelajaran humanistik ini adalah pembelajaran kooperatif , tandur dan CTL.

Pada Psikologi humanistik pendidik sebagai fasilitator. Pendidik merupakan pendidik yang manusiawi yang paham terhadap gaya belajar dan sikap peserta didiknya. Pendidik mengarahkan siswa untu mengembangkan dirinya sesuai dengan kemampuan-kemampuan intelegesi yang dimiliki. Pendidik membimbing peserta didik tidak membebani peserta didik dalam proses pembelajaran tetapi menanamkan nilai-nilai atau perilaku positif dan perilaku negatif.

Dalam Teori Belajar Humanisme menjadikan peserta didik meningkatkan potensi dirinya baik inelegensi dan bakatnya. Manusia bisa mempertanggungjawabkan tindakan positif dan negatif sebagai pilihan kehidupan,tindak-tanduk positif digunakan untuk membangun diri kearah yang lebih baik, untuk mengaktulisasikan potensi diri.

Tujuan belajar paham humanisme menjadikan memanusiakan manusia. Kegiatan pembelajaran akan berhasil ketika peserta didik melek terhadap lingkungan sekitar dan dirinya sendiri.Teori ini menitikberatkan gaya peserta didik dalam belajar. Pendidik hanya mengarahkan peserta didik agar belajar dengan baik.

Teori belajar humanisme beranggapan perilaku peserta didik ditentukan oleh diri sendiri bukan lingkungan dan pengetahuan. Sehingga peserta didik menemukan aktualisasi diri mereka. Kebermaknaan aktualisasi diri sendiri maupun oleh lingkungan. Dalam artian peserta didik bisa memotivasi diri sebagai faktor internal diri peserta didik. Kebermaknaan proses belajar berdasarkan pengalaman peserta didik secara langsung, memikirkan, merasakan, kehendak sendiri serta melibatkan seluruh potensi kepribadian peserta didik. Belajar bermakna merupakan belajar untuk memenuhi kebutuhan nyata individu. Pandangan teori humanisme, ciri pendidik harus bisa memberikan : 1) motivasi belajar peserta didiknya,2) empati dan terbuka, serta kehangatan. Sikap empati pendidik terhadap peserta didik bukan hanya berupa kata-kata tapi perbuatan untuk membantu peserta didik. Keterbukaan pendidik untuk mengarahkan diri, menerima kritikan, menerima masukan, mau dinilai, dan menerima ujian. Keaslian pendidik berupa bersikap tidak dibuat-buat. Kekonkretan bisa bertanggung jawab sesuai dengan kemampuan yang dicapai peserta didik dengan kebenaran hasil yang ada. 
Kehangatan pendidik dalam berkomunikasi membuat mereka nyaman dan keikhlasan dalam memberikan pelayanan. Dalam teori humanistik kreativitas siswa dan kemampuan critical thinking sangat diharapkan sehingga mereka bisa menghadapi dampak negatif

Teori belajar humanisme dipelopori oleh Abraham Maslow, Arthur Combs dan Carl Rogers :

a) Abraham Maslow

Maslow adalah pelopor teori belajar humanistik dengan teori kebutuhan (Hierarchy of Needs). Maslow berpendapat manusia dapat memahami dan menerima dirinya sebisa mungkin. Adapun 5 kebutuhan manusia yang disampaikan Maslow yaitu:1) Kebutuhan fisiologis ,2) Kebutuhan aman dan tenteram, 3) Kebutuhan dicintai dan disayangi, 4) Kebutuhan untuk dihargai, 5) Kebutuhan meningkatkan aktualisasi diri.

\section{b) Arthur Combs}

Bersama dengan Donald Syngg ( 1904 - 1967 ) menjelaskan tentang Meaning. Belajar dikatakan berhasil jika ada kebermaknaan yang dicapai peserta didik baik materi maupun bermakna bagi kehidupannya sendiri. Pendidik bukan memberikan materi yang tidak disenangi dan tidak sesuai dengan kehidupan pesert didik. Sehingga pendidik memahami tingkah laku dengan mengkontruk dunia peserta didik itu, jadi ada perubahan tingkah laku maka pendidik bisa membuat keyakinan positif peserta didik. Combs menyatakan pendidik sering keliru dalam pembelajaran, pendidik sukses mengajar jika sudah menyampaikan materi kepada siswa secara sistematik. Tapi tidak menyatu pada materi pelajaran dengan perilaku peserta didik. Belajar berarti bagi kepribadiannya dan siswa bisa menganalisa permasalahan kehidupannya. Combs menjelaskan gambaran dari diri peserta didik berupa lingkaran kecil dan dunia berupa Lingkaranbesar.

\section{c) Carl Rogers}

Carl Roger menyatakan saling toleransi dan tidak ada prasangka dalam mengatasi permasalahan dalam hidup. Pendidik harus menekankan supaya pembelajaran aktif yaitu :

1. Membelajarkan manusia. Siswa tidak belajar tentang materi-materi tidak bermanfaat bagi diri mereka sendiri.

2. Siswa mempelajari materi bermakna bagi dirinya. Bahan pelajaran dikembangkan menjadi materi dan konsep baru sehingga ada makna pembelajaran

3. Penyusunan sistematik materi pengajaran berarti menyusun materi dan konsep baru menjadi materi memiliki makna yang tinggi untuk peserta didik

4. Siswa belajar dengan kebermaknaan pada lingkungan modern dapat diartikan siswa belajar dengan system yang baik.

Teori belajar humanistik pada bukunya Freedom to learn, yaitu: 1) manusia itu mempunyai kemampuan belajar secara alami,belajar terjadi apabila materi pelajaran dirasakan murid relevan dengan halhal tersendiri, 2) adanya perubahan belajar dalam hal dirinya sendiri yang mengancam dan ditolak, 3) belajar dengan penuh makna di peroleh siswa dengan mengerjakannya, 4) siswa dilibatkan di proses pembelajan dan ikut dalam proses belajar itu (Zagoto., M. M., \& Nevy, Y., 2018)

Roger menyatakan ciri-ciri pendidik yang memfasilitasi peserta didik yaitu :1)merespon perasaan siswa, 2) mengembangkan ide-ide siswa dalam interaksi yang dirancang, 3) dialog dan diskusi dengan siswa, 4) menghargai siswa, 5) perilaku dan perbuatan sesuai,6) isi kerangka berpikir siswa disesuaikan (penjelasan memenuhi kebutuhan siswa, 7) memberikan senyum kepada siswa (Zagoto, 2019; Sarumaha, 2018).

Pada penelitian ini, pendidik sebagai fasilitator dapat meningkatkan motivasi belajar siswa dan tidak ada lagi siswa yang bolos sekolah, aktualisasi siswa semakin meningkat, Kemampuan akademik di bidang matematika dan bahasa dapat dikatakan berhasil, siswa semakin disiplin, jiwa critical thinkin (Zagoto., M. M., \& Dakhi, O., 2018).

Teori belajar humanisme, peserta didik belajar ingin mengetahui dunia mereka. Individu menentukan hal yang dipelajari, mengusahakan ingin tahu dunia di sekitarnya dan belajar dengan proses merekasendiri.

\section{SIMPULAN}

Teori belajar humanistik menekan pendidik sebagai fasilitator. Pendidik-pendidik yang hebat merupakan pendidik-pendidik yang bisa menjadikan manusia seutuhnya. aliran humanistik mengarahkan untuk meningkatkan potensi diri dan intelegensi sehingga bisa menjawab tantangan global baik positif maupun negatif. Pendidik memberikan bimbingan yang membebaskan secara positif pada siswa dalam kegiatan pembelajarannya, sehingg nilai-nilai atau norma diterima secara kaffah memberikan informasi padanya tentang perilaku positif dan perilaku negatif yang seharusnya tidak dilakukannya. 


\section{DAFTAR PUSTAKA}

Dakhi, O. "Aplikasi Pendeteksian Kerusakan File Akibat Virus Dengan Menggunakan Metode Heuristic." Pelita Informatika Budi Darma, vol. 4, no. 1, pp. 35-41, 2013.

Dakhi, O. 2013. Belajar Javascript Dengan Mudah Dan Detail. Jakarta: Dapur Buku. pp. 1-202.

Khairani, Makmun. 2014. Psikologi Belajar. Yogyakarta: Aswaja Pressindo.

Ormrod, Jeanne Ellis. 2008. Psikologi Pendidikan. Alih bahasa Amitya Kumara. Jakarta: Erlangga.

Rachmana, Ratna, 2018. Psikologi Humanistik dan Aplikasinya dalam Pendidikan, https://socius.ppj.unp.ac.id/index.php/socius,Vol.7,No.3 hal .19-26

Sarumaha, R., Harefa, D., \& Zagoto, Maria M. (2018). Upaya Meningkatkan Kemampuan Pemahaman Konsep Geometri Transformasi Refleksi Siswa Kelas XII-IPA-B SMA Kampus Telukdalam Melalui Model Pembelajaran Discovery Learning Berbantuan Media Kertas Milimeter. Jurnal Education and development, Vol.6 No.1, 90-96. https://doi.org/10.37081/ed.v6i1.668

Santrock, John W. 2008. Psikologi Pendidikan. Alih bahasa Tri Wibowo B.S., Jakarta: Kencana.

Slavin, Robert E. 2008. Educational Psycology: Theory and Practice. Alih bahasa Marianto Samosir. Jakarta: PT. Indeks.

Suryabrata, Sumadi. 2010. Psikologi Pendidikan. Jakarta: PT. Raja Grafindo Persada.

Zagoto, Maria M., Yarni, Nevi; Dakhi, O. (2019). Perbedaan Individu dari Gaya Belajarnya Serta Implikasinya Dalam Pembelajaran. Jurnal Review Pendidikan dan Pengajaran, 2(2), 259265.

Zagoto, Maria M. \& Dakhi, O (2018). Pengembangan Perangkat Pembelajaran Matematika Peminatan Berbasis Pendekatan Saintifik Untuk Siswa Kelas XI Sekolah Menengah Atas. Jurnal Review Pendidikan dan Pengajaran, 1(1), 157-170.

Zagoto, Maria M. (2018). Pengembangan Perangkat Pembelajaran Matematika Berbasis Realistic Mathematic Educations Untuk Siswa Kelas V Sekolah Dasar, Jurnal Education And Development, vol. 3, no. 1, p. 53, Feb. 2018. https://doi.org/10.37081/ed.v3i1.139 